\title{
MEASURING THE IMPACT OF EXTRINSIC CUES ON CONSUMERS' PURCHASING DECISION FOR FOOD PRODUCTS
}

\author{
Besnik FETAI* \\ South East European University, Tetovo, Macedonia \\ Nora SADIKU-DUSHI \\ South East European University, Tetovo, Macedonia

\section{Raman ISMAILI} \\ State University of Tetova, Tetovo, Macedonia
}

\begin{abstract}
The extrinsic product cues are becoming a very important aspect in product evaluation by consumers. Because of their importance many authors are exploring which extrinsic cues are considered more significant when evaluating the different kind of products. Therefore, the aim of this research is to investigate the impact of most researched extrinsic cues such as the country of origin (COO), brand, and price on a purchasing decision for food products among consumers in Kosova. To explore the domestic country bias, the impact of the additional cue labeled as "domestic product" is studied. Based on a quantitative survey, the main findings of this study revealed that the brand, the price, the country of origin, and domestic branded products have positive impact on a consumer's purchasing decision, since consumers rely on those extrinsic cues when making their purchasing decisions. When multiple cues are presented, the country of origin is considered as the most important cue, while the "domestic product" is least important to Kosovar consumers. The findings of this study are useful to food producers and marketers of food products, since it can provide them with useful information on what consumers consider most important when purchasing food products.
\end{abstract}

JEL classification: M31, C35;

Keywords: extrinsic cues, brand, country of origin, price.

\footnotetext{
${ }^{*}$ Corresponding author. Address: South East European University, Tetovo, Macedonia, E-mail: b.fetai@seeu.edu.mk
} 


\section{Introduction}

The aim of this research is to investigate the impact of extrinsic cues such as the country of origin ( $\mathrm{COO}$ henceforth), brand name, and price on purchasing decision for food products among Kosovar consumers. Many authors have conducted different studies in this field to measure the impact of extrinsic cues on consumers' perception on the quality of the products (Teas and Agarwal, 2000; Szybillo and Jacoby 1974, Miyazaki, Grewal, and Goodstein, 2005; Zeithaml, 1988; Rao and Monroe, 1989; Kirmani and Zeithaml 1993; Bredahl, 2004), risk perception (Shimp and Bearden, 1982; Aqueveque, 2006; Agarwal and Teas, 2001; Huang, Schrank and Dubinsky, 2004), product evaluation (Bilkey and Nes, 1982; Rao and Monroe, 1988) and purchase intention (Dodds, Monroe and Grewal, 1991: Grewal, Krishnan, Baker and Borin, 1998; Chu, Choi and Song, 2005; Cordell, Wongtada and Kieschnick, 1996). Price, brand (Bredahl, 2004), and COO (Al-Sulaiti and Baker, 1998) are considered to be the most studied extrinsic cues.

Despite numerous researches on the subject of extrinsic cues, there is little evidence about the impact of $\mathrm{COO}$, brand, and price on consumers' purchasing decision. Since the research took place in Kosovo, apart from the chosen extrinsic cues the impact of the additional cue labeled as "domestic product" is studied.

Kosovo is a small country with an area of $10,908 \mathrm{~km}^{2}$, located in Southeast Europe. According to Kosovo Agency of Statistics the approximate population in Kosovo is 1.78 million. Kosovo is a country with a negative trade balance since imports exceed its exports. Total exports for year 2016 were 309,6 million Euro while imports for the same year were 2,789.5 million Euro ("Kosovo Agency of Statistics", 2017). As most of the food products in the Kosovar market are imported, the 'cues' such as COO, brand, price, and domestic products are purposively selected for this study since Kosovar consumers must rely on those cues when making their final purchasing decision.

To fulfil the gap in the literature we attempt to answer the following research question:

1) Do extrinsic product cues impact the consumers' purchasing decision for food products?, and

2) Which extrinsic cue is considered to be the most important when making a purchasing decision for food products?

The following hypothesis will be tested:

$\mathrm{H} 1$ : There is a significant impact of the product's brand name on the purchasing decision for food products.

$\mathrm{H} 2$ : There is a significant positive impact of the product's price on the purchasing decision for food products.

H3: There is a significant relationship between "domestic product" brands and purchasing decision for food products

$\mathrm{H} 4$ : There is a significant impact of the product's $\mathrm{COO}$ on the consumer purchasing decision for food products.

To test the research hypothesis, we applied the binary logit regression model. By adopting the quantitative research method, the data was collected by the means of a structured questionnaire, distributed to 100 respondents, based on convenience sampling. 
The current study makes the following main contribution. Firstly, it explores the impact of the selected extrinsic cues on the purchasing decision, by also identifying which is the most important extrinsic cue when Kosovar consumers make their purchasing decision. Secondly, the study will try to fill at least a part of the gap in a literature regarding the extrinsic cues impact on purchasing decision. And thirdly, this study will possibly raise the interest of other scholars and researchers in developing this research field.

The paper is organized as follows: the next section presents the literature review, followed by data presentation and the research methodology. The fourth section presents the empirical analysis, while the fifth section presents the conclusions and the recommendation for further research.

\section{Literature review}

Products are the collection of attributes known as 'cues' which are used by consumers to create an impression about the specific product. Those 'cues' can be intrinsic or extrinsic (Olson and Jacoby, 1972). The intrinsic product cues are product features that are part of the product itself while extrinsic cues are not part of the product but are related to the product (Idoko et al., 2013) such as brand, COO and price (Lee and Lou, 1995), store name (Teas and Agarwal, 2000) promotion, presentation (Acebron and Dopico, 2000) warranty, manufacturer reputation (Bearden and Shimp, 1982), packaging (Mueller and Szolnoki, 2010) and advertising (Milgrom and Roberts, 1986).

Many studies found that consumers rely on product cues when they form their overall evaluation regarding different products. Product cues are defined as stimuli that play informational role before product consumption (Ahmed et al., 2004). Some studies found that extrinsic product cues can be more important than intrinsic cues, especially in initial buying where intrinsic cues are unavailable or when assessment of the intrinsic cues takes time and effort (Sawyer, Worthing, \& Sendak, 1979). Therefore, according to Zeithaml (1988) the extrinsic cues are used as quality indicators when consumer has to make a decision without sufficient information on intrinsic attributes, especially in cases when the consumer has no experience with the product, has no time and has lack of interest in evaluating the intrinsic attributes or is unable to evaluate them (Zeithaml, 1988). According to literature, the most studied extrinsic cues are brand, COO, and price.

Brand as an extrinsic cue is considered a name, a term, a symbol, a sign, or a combination off all these and is intended to identify and differentiate a product or service of one seller comparing to other sellers (Kotler, Keller, Manceau, \& HémonnetGoujot, 2015). According to Kotler et al. (2015), the brand represents a promise of the seller to deliver a set of characteristics, benefits and services to the consumer. Brand name is a very frequently extrinsic cue used to collect or keep quality perceptions and can represent a set of information about a product (Richardson, Dick, and Jain, 1994). The reduction of uncertainty is one of the most important roles that brand plays in a consumer's purchasing decision process (Auger, Devinney, Louviere, and Burke, 2010). It is also considered that brand reduces consumer confusion by acting as a signal of product quality (Erdem and Swait, 1998), moreover consumers perceive the brand as a sign of quality and then they evaluate other criteria such as packaging, price, physical appearance (Vraneševic, and Stančec, 2003). Many studies show that consumers in emerging economies rely on brand considering that common product 
information are not enough reliable and available (Zhou, Su, and Bao, 2002; Maxwell, 2001). There are also several studies that explained the reasons why emerging countries rely on brands. According to Bearden and Etzel (1982), imports are usually more expensive than local alternatives and that is the reason that makes foreign brands more attractive and desirable. Hannerz (1990) observed that the desire to feel like cosmopolitan in a world that is interconnected is a reason that consumers in developing countries tend to consume branded products. Based on the previous findings in literature the following hypothesis is proposed:

$\mathrm{H} 1$ : There is a significant impact of the product's brand name on the costumer purchasing decision for food products.

Price is also considered as an important extrinsic cue, especially when consumers do not have sufficient information about intrinsic cues, or in cases when it is the only cue that is available (Zeithaml, 1988). Many studies found that price and quality are positively related (Dodds, Monroe and Grewal, 1991; Rao and Monroe, 1989). There is a believing that consumers tend to categorize products according to price by considering that qualitative products are expensive, while lower quality products are less expensive (Acebrón and Dopico, 2000; Kardes, Cronley, Kellaris, and Posavac, 2004). Therefore, if consumers believe that price and quality are linked, paying a lower price means accepting lower quality. Contrary, to get a better quality, a consumer must be ready to make a financial sacrifice (Veale, Quester and Karunaratna, 2006). It is a real challenge for many consumers in finding a suitable balance between those two, therefore it means that price plays a significant and exclusive role in the purchasing decision (Kardes et al., 2004;). According to Veale et al. (2006), consumers tend to rely even more on price, especially in cases when they do not possess or possess limited information of product category offerings. Monroe and Krishnan (1985) found that the price is used as an important cue in cases of unbranded products and therefore it is used as information indicator when there is not enough information about the brand. The price cue is found to be used also in cases when the consumer motivation is low (Mitra, 1995). But there are also studies that oppose the statements that the price level is an indicator of quality. Bredahl (2004) in a study of cue utilization regarding the branded beef found that the price is not considered as a significant quality cue, since the beef consumers in his study do not link beef quality to the price because they consider that a very high quality beef can be sometimes found at a lower price, therefore, they do not consider the price as a reliable product cue. On the basis of the evidence that the price is considered important when making the purchasing decision, the following hypothesis is specified:

$\mathrm{H} 2$ : There is a significant positive impact of the product's price on purchasing decision for food products.

$\mathrm{COO}$ as one of the extrinsic cues has been broadly studied into research literature (Dinnie, 2004). COO of the product in literature is generally defined as the country where the product is manufactured. According to Auger et al. (2010), the study of $\mathrm{COO}$ can be broadly divided into two categories; one that studies consumer approach toward different country products and the other that studies the domestic country product bias. The domestic country bias can be described as a consumer's preference toward purchasing domestic products over foreign products (Balabanis and Diamantopoulos, 2004), and in many studies is linked to consumer ethnocentrism 
that is explained as a responsibility and morality of buying domestic products (Shimp and Sharma, 1987). According to Agrawal and Kamakura (1999) if consumers have a positive or negative image about a specific product or country they may generalize that attitude toward all the products coming from that particular country. Some recent studies have linked the COO effect with the consumer ethnocentrism which is based on the morality and responsibility of buying homemade products (Watson and Wright, 2000). Based on the above the following is hypothesized:

H3: There is a significant relationship between "domestic product" brands and purchasing decision for food products

Kotler and Gertner (2002) pointed out that the impact of COO differs depending on the type of the product. Studies on the COO impact have focused on high involvement products (ex. electronics, cars) then for low involvement products (like food and beverages) (Ahmed et al., 2004). It is found that COO is more pronounced in purchasing a high involvement product (Li and Wyer, 1994), than it is in low involvement products due to the low financial and hedonistic value for the consumer (Ahmed et al., 2004). When buying low involvement products $\mathrm{COO}$ does matter, but when other cues as brand and price are present the impact of $\mathrm{COO}$ weakens and brands becomes an important factor (Ahmed et al., 2004). Studies conducted by Peterson and Jolibert (1995) and Verlegh and Steenkamp (1999) found that the COO effect is smaller when COO is studied in multi cue research than when $\mathrm{COO}$ is studied as a single product cue.

Therefore, the following hypothesis is proposed:

$\mathrm{H} 4$ : There is a significant impact of the product's COO on the consumer purchasing decision for food products.

Even though there is still no consensus among the researchers on which of the extrinsic cues are mostly important, they all agree that extrinsic cues do have an impact on the buying decision process.

Purchasing decision is one of the stages in the buying decision process. The buying decision process was first introduced in 1968 by Engel, Kollat and Blackwell known as the EKB model (Lin and Chen, 2006). According to the EKB model the buying decision is described as a continuing process which includes five stages: recognition of need, information search, alternative valuation, the purchase decision and behavior after purchase (Darley, Blankson and Luethge, 2010). These five stages are widely accepted and used by many scholars. The purchasing decision is the fourth stage of the purchase decision process, and is the stage where the actual decision to purchase or not to purchase takes place.

In this study, the purchasing decision is treated as a dependent variable with dichotomous outcome as a simple decision to purchase or not to purchase.

\section{Data and Research Methodology}

To test the research hypothesis, the quantitative research method was used. It is considered that quantitative methods are appropriate methods for studying the different phenomena in social reality, and are especially suited for hypothesis testing (Sukamolson, 2007). The other reason for choosing quantitative research approach is to determine the relation between independent and dependent variables defined in the study (Hopkins, 2008). 
Given that questionnaires are found to be the most common technique for data collection in quantitative studies (Bryman, 2006), we opted for a fully structured questionnaire. Since the study took place in Kosova the questionnaire was designed in Albanian language. Before distributing it was pre -tested in a small pilot-group in order to ensure that all respondents clearly understand all the questions in the survey and they have no doubts when answering them. As suggested by Czaja (1998), the group of respondents was asked to fill the questionnaire and then they were asked if they understood the wording, phrases and questions, and, if they eventually had difficulties in answering the questionnaire. After ensuring that the questions were understandable for every participant in pilot-group, the questionnaire was personally distributed by the researcher to 100 respondents selected by convenience sampling in the city of Pristina, Gjilan and Ferizaj during a period of 30 days (June, 2017). Convenience sampling as non probability sampling technique is very frequently used in quantitative studies because it is considered as an affordable and easy technique for the researcher (Etikan, Musa \& Alkassim, 2016) where samples are more accessible to the researcher (Suen, Huang, \& Lee, 2014). As Dornyei (2007) suggests, it meets the criteria such as easy time availability, and geographical closeness.

The questionnaire consists of 20 questions divided in three parts: respondent's basic information (six questions: gender, place of residence, age-group, education, employment, and average monthly income), thirteen questions related to extrinsic cues and one question focused on the purchasing decision. The questions in the respondent's basic information part were closed -ended multiple choice, while the questions about the extrinsic cues were 5-point Likert-scale statements which enabled respondents to express their level of agreement-or disagreement with the respective statements. In terms of measuring the purchase decision a dichotomous (binary) measure was used by classifying the respondents' decision to (1) purchase and (0) don't purchase. It is suggested that dichotomous or binary scale is more practical especially when measuring the consumer preferences in developing countries due to the respondents' lack of knowledge and the difficulty they face in answering or giving judgments in continuous scales and longer list of stimuli (Malhotra, 1988).

To give more meaning to the collected data, the questions about extrinsic cues used in the questionnaire were grouped by their relevance into four independent variables named Brand, COO, Domestic Product, and Price. To determine the internal consistency of the new created variables, especially those using a Likert scale items it is recommended to test the reliability of scales using Cronbach's alpha (Gliem and Gliem, 2003). The reliability test results are given in the Table 1.

Table 1. Reliability test

\begin{tabular}{lcc}
\hline New variables & Number of items* & Cronbach's alpha $^{*}$ \\
\hline Brand & 3 & 0.8329 \\
Price & 3 & 0.7368 \\
COO & 4 & 0.7903 \\
Domestic_product & 3 & 0.8740 \\
\hline
\end{tabular}

Source: Authors calculation

* The number of items refers to the number of questions that were grouped to form the new 
Table 1 shows the values of Chronbach's alpha for all the four variables used in the study. The value of alpha ranges from 0 to 1 and it is considered that the higher the score of the coefficient, the more reliable is the scale (Santos, 1999). Since the acceptable alpha values are suggested to be in a range from 0.70 to 0.95 (Tavakol and Dennick, 2011) it is considered that all the items measured in this study are reliable and have relatively high internal consistency.

\section{Empirical Analysis}

\subsection{Profile of respondents}

The respondent basic information covered gender, place of residence, agegroup, education, employment, average monthly income. The demographic profile of the respondents is presented in the Table 2.

Table 2. Profile of respondents

\begin{tabular}{llll}
\hline Description & Percentage & Description & Percentage \\
\hline $\begin{array}{l}\text { Gender } \\
\text { Female }\end{array}$ & $58 \%$ & Place of residence & \\
Male & $42 \%$ & $\begin{array}{l}\text { Village } \\
\text { City }\end{array}$ & $37 \%$ \\
& & & $63 \%$ \\
Age group & & Employment & \\
$18-25$ & $18 \%$ & Unemployed & $39 \%$ \\
$26-35$ & $49 \%$ & Self-employed & $9 \%$ \\
$36-45$ & $11 \%$ & Employed in private sector & $41 \%$ \\
$46-55$ & $13 \%$ & Employed in government sector & $11 \%$ \\
above 56 & $9 \%$ & Average monthly income & \\
& & Less than 200 Euro & $28 \%$ \\
Education & $1 \%$ & $201-400$ Euro & $33 \%$ \\
Primary school & $1 \%$ & $401-700$ Euro & $24 \%$ \\
Secondary school & $20 \%$ & $701-1000$ Euro & $8 \%$ \\
Bachelor & $65 \%$ & Above 1000 Euro & $7 \%$ \\
Master & $10 \%$ & & \\
PhD & $4 \%$ & & \\
\hline
\end{tabular}

Source: Authors Calculation

The data shows that 58 percent of the respondents were females. 63 percent of the total sample lives in a city. Almost half of the respondents are in the age group of 26-35 years old (49 percent). Their educational background is mostly bachelor degree (65 percent). The respondents are mainly employed in the private sector (41 percent), and average monthly income for the most of them lies between 201-400 Euro (33 percent). 


\subsection{Econometric Modelling}

Since the outcome in this study is dichotomous (measuring consumers' purchasing decision as simply "purchasing" or "not purchasing") the use of binary logit regression is seen as a most appropriate model in order to test the given hypothesis (Tranmer, and Elliot, 2008). The use of logistic regression is also seen as a very useful technique for modelling and solving problems in marketing, since many marketing problems deal with the dichotomous outcomes and this model is found to generate more suitable and accurate findings in terms of model fit and correctness of analysis (Akinci, Kaynak, Atilgan and Aksoy, 2007). The chosen sample is also suitable for performing binary logit regression based on the general rule of thumb that recommends the number of no less than 50 participants and increasing this number by adding the number of independent variables (VanVoorhis and Morgan, 2007). Green (1991) also suggested the minimum number of subjects for conducting a regression analysis should be based on this rule $\mathrm{N}>50+8 \mathrm{~m}$ (where $\mathrm{m}$ is the number of predictors), which is also compatible with the number of participants in our study.

Therefore, the specification of the model is following:

$$
\mathrm{Pi}=\operatorname{Pr}(\mathrm{Yi}=1 \mid \mathrm{Xi}=\mathrm{xi})=\frac{\exp (\beta 0+\beta 1 \mathrm{xi})}{1+\exp (\beta 0+\beta 1 \mathrm{xi})}
$$

Or using a logit function this could be written as:

$$
\operatorname{logit}(\mathrm{Pi})=\log \left(\frac{\mathrm{Pi}}{1-\mathrm{Pi}}\right)=\beta 0+\beta \mathrm{i} x i
$$

In our case $Y$ is a dependent variable that represents purchase decision and takes values 1 and 0 (1-when making a purchase and 0 - when not making a purchase) and $X_{1}, X_{2}, X_{3}$ and $X_{4}$ are independent variables (COO, brand, price and domestic product).

\subsection{Research Results}

The questions in all the variables were statements on a 5-point Likert scale, ranging from completely agree (1) to completely disagree (5). For the easier interpretation and data handling these responses were transformed into dummy variables. First, the mean in every variable was found and then all the responses below the mean were coded as 1 (agree), while the responses above the mean were coded as 0 (disagree). The binary logistic regression is presented in the Table 3 while its odd ratio is reported in Table 4.

Table 3. Binary Logistic Regression Model

\begin{tabular}{lllll}
\hline Purchase decision & Coef. & Std. Err. & $\mathrm{Z}$ & $\mathrm{P}>(\mathrm{z})$ \\
\hline Brand & 2.052676 & 0.7164897 & 2.86 & 0.004 \\
Country of origin & 3.834525 & 0.9789729 & 3.92 & 0.000 \\
Domestic product & 1.829388 & 0.7350813 & 2.49 & 0.003 \\
Price & 3.18335 & 0.8801696 & 3.62 & 0.000 \\
\hline
\end{tabular}

Source: Authors Calculation 
Testing the impact of brand on consumer purchasing decision. According to the regression results shown in Table 3, the p-value that defines a good of fitness for the independent variable brand is $0.004<0.05$ which shows that it is statistically significant. Since the $z$ value for the brand is 2.86 and positively exceeds the critical value of 1.96 , it can be claimed that on a confidence level of $95 \%$ the brand has a significantly positive impact on consumer purchase decision. Therefore $\mathrm{H} 1$ is supported.

Testing the impact of price on consumer purchasing decision. The p-value for the price is $0.000<0.05$ shows that the statistical significance is reached. The $z$ value positively surpasses the critical value of 1.96 , therefore we can conclude that at the 95\% confidence level, the price has a positive impact on a purchasing decision. Therefore, the $\mathrm{H} 2$ is strongly supported.

Testing the impact of domestic products on consumer purchasing decision. Also the domestic product variable has a p-value of $0.013<0.05$ meaning that is statistically significant. The critical z value of 1.96 at a confidence level of $95 \%$ is positively exceeded which means that domestic product brands have a positive impact on a purchasing decision. Therefore, the $\mathrm{H} 3$ is also supported.

Testing the impact of $\mathrm{COO}$ on the consumer purchasing decision. The above results show that the $p$-value for the independent variable $\mathrm{COO}$ is $0.000<0.05$ which shows that it reaches the statistical significance. The $z$ value also positively exceeds the critical value of 1.96 and shows that at 95\% confidence level, the product's country of origin has a significant impact on consumers purchasing decision; therefore, we can claim that $\mathrm{H} 4$ is strongly supported.

Table 4. Odds Ratios

\begin{tabular}{lllll}
\hline Purchase decision & Odds Ratio & Std. Err. & $\mathrm{Z}$ & $\mathrm{P}>(\mathrm{z})$ \\
\hline Brand & 7.788717 & 5.580536 & 2.86 & 0.004 \\
Country of origin & 46.27145 & 45.29849 & 3.92 & 0.000 \\
Domestic product & 6.230071 & 4.579609 & 2.49 & 0.003 \\
Price & 24.12745 & 21.23624 & 3.62 & 0.000 \\
\hline
\end{tabular}

Source: Authors Calculation

The importance of extrinsic cues on the purchasing decision can be also seen from the odd ratios given in Table 4, where the odds for purchasing instead of not purchasing the products based on the product brand are nearly 8 times higher in favor of purchasing. The same situation is also when deciding to purchase based on COO where odds are 47 times higher in favor of purchasing. The odds of purchasing based on a product price are 26 times higher in favor of purchasing. The lowest odds are reported in buying domestic branded products. The odds in this case are much lower than in all other extrinsic cues and are only 6 times in favor of purchasing.

The results in this study show that every extrinsic cue is important and have a positive impact on a purchasing decision. But, since this study was a multiple cue study where four extrinsic cues were presented to the respondents, following the suggestions by Azen and Traxel (2009) using a dominance analysis we have determined 
the relative importance of every cue individually and their impact on a dependent variable in the logistic regression model that we used. Based on the dominance analysis presented in Table 5, COO resulted as the most important cue when Kosovar consumers make their food purchasing decisions, followed by price, brand and domestic branded products.

Table 5. Dominance Analysis

\begin{tabular}{llll}
\hline Purchasing Decision Dominance Statistics & Standardized dominance statistics & Ranking \\
\hline Brand & 0.1625 & 0.2744 & 3 \\
CoO & 0.2052 & 0.3465 & 1 \\
Domestic Product & 0.0475 & 0.0802 & 4 \\
Price & 0.1770 & 0.2989 & 2 \\
\hline
\end{tabular}

Source: Authors Calculation

\section{Conclusion}

The main objective of this research was to explore the impact brand, price, CCO and domestic product on a Kosovar consumers purchasing decision. Besides, the other objective was to find out which of these extrinsic cue is considered most important when multiple cues are presented to consumers.

The main findings of this study revealed that the brand, price, COO and domestic branded products have positive impact on a consumer's purchasing decision. In view of the fact that kosovar consumers do rely on those extrinsic cues when making their purchasing decision and consider those cues as very important. Those findings are in general consistent with the findings from previous studies in this field.

The results show that when multiple cues are presented, consumers consider $\mathrm{COO}$ as most important, followed by price, brand and domestic product brands.

The most surprising finding in this study is that $\mathrm{COO}$ is considered as the most important cue when multiple cues are presented to the consumer, which is contrary to the studies conducted by Peterson and Jolibert (1995) and Verlegh and Steenkamp (1999) who found that the COO effect is smaller when is studied in multi cue research than when $\mathrm{COO}$ is studied as a single product cue. The results also are not in line with the findings of Ahmed et al. (2004), according to whom the COO is not pronounced in low involvement product such food and beverages, and the impact if $\mathrm{COO}$ weakens when brand and price are presented as additional cues, and the brand becomes the most important factor.

Even that domestic food brands are considered important, when presented together with other cues they are listed as the least important cue when purchasing food products, therefore the kosovar consumers may not be considered as ethnocentric, since they consider all other cues more important than domesticlabeled products. 
The findings are useful to food producers and marketers that deal with production or sale of food products, since it can give them a clearer view of what consumers consider more important when purchasing food products.

This study has some limitations. Firstly, all the food products were generally examined in the study, and therefore specific food products may generate different results. Secondly, the limited number of extrinsic cues was employed. Thirdly, the study was based on the convenience sampling technique and the sample size was limited to only 100 cases therefore the findings cannot be generalized. Fourthly, the results are limited to Kosovar consumers only.

However, despite the limitations this study has opened some new insights on the impact of extrinsic cues on the consumer's purchasing decision and has offered a significant contribution to related literature by being the first study in this field conducted in Kosova.

It is recommended that in order to produce more reliable results, future studies could focus on investigating the larger sample of respondent, investigating other product cues, including other product types to the study or employing other research methodology.

\section{References}

Acebrón, L. B., \& Dopico, D. C. (2000). The importance of intrinsic and extrinsic cues to expected and experienced quality: an empirical application for beef. Food Quality and Preference, 11(3), 229-238.

Agarwal, S., \& Teas, R. K. (2001). Perceived value: mediating role of perceived risk. Journal of Marketing theory and Practice, 9(4), 1-14.

Agrawal, J., \& Kamakura, W. A. (1999). Country of origin: A competitive advantage?. International Journal of Research in Marketing, 16(4), 255-267.

Ahmed, Z. U., Johnson, J. P., Yang, X., Kheng Fatt, C., Sack Teng, H., \& Chee Boon, L. (2004). Does country of origin matter for low-involvement products?. International Marketing Review, 21(1), 102-120.

Akinci, S., Kaynak, E., Atilgan, E., \& Aksoy, Ş. (2007). Where does the logistic regression analysis stand in marketing literature? A comparison of the Market Positioning of Prominent Marketing Journals. European Journal of Marketing, 41(5/6), 537-567.

Al-Sulaiti, K. I., \& Baker, M. J. (1998). Country of origin effects: a literature review. Marketing Intelligence \& Planning, 16(3), 150-199.

Aqueveque, C. (2006). Extrinsic cues and perceived risk: the influence of consumption situation. Journal of Consumer Marketing, 23(5), 237-247.

Auger, P., Devinney, T. M., Louviere, J. J., \& Burke, P. F. (2010). The importance of social product attributes in consumer purchasing decisions: A multi-country comparative study. International Business Review, 19(2), 140-159.

Azen, R., \& Traxel, N. (2009). Using dominance analysis to determine predictor importance in logistic regression. Journal of Educational and Behavioral Statistics, 34(3), 319-347.

Balabanis, G., \& Diamantopoulos, A. (2004). Domestic country bias, country-of-origin effects, and consumer ethnocentrism: a multidimensional unfolding approach. Journal of the Academy of Marketing Science, 32(1), 80-95. 
Bearden, W. O., \& Etzel, M. J. (1982). Reference group influence on product and brand purchase decisions. Journal of consumer research, 9(2), 183-194.

Bearden, W. O., \& Shimp, T. A. (1982). The use of extrinsic cues to facilitate product adoption. Journal of marketing research, 229-239.

Bilkey, W. J., \& Nes, E. (1982). Country-of-origin effects on product evaluations. Journal of international business studies, 13(1), 89-100.

Bredahl, L. (2004). Cue utilisation and quality perception with regard to branded beef. Food quality and preference, 15(1), 65-75.

Bryman, A. (2006). Integrating quantitative and qualitative research: how is it done? Qualitative research, 6(1), 97-113.

Chu, W., Choi, B., \& Song, M. R. (2005). The role of on-line retailer brand and infomediary reputation in increasing consumer purchase intention. International Journal of Electronic Commerce, 9(3), 115-127.

Cordell, V. V., Wongtada, N., \& Kieschnick, R. L. (1996). Counterfeit purchase intentions: role of lawfulness attitudes and product traits as determinants. Journal of Business Research, 35(1), 41-53.

Czaja, R. (1998). Questionnaire pretesting comes of age. Marketing Bulletin-Department of Marketing Massey University, 9, 52-66.

Darley, W. K., Blankson, C., \& Luethge, D. J. (2010). Toward an integrated framework for online consumer behavior and decision making process: A review. Psychology \& marketing, 27(2), 94-116.

Dinnie, K. (2004). Country-of-origin 1965-2004: A literature review. Journal of Consumer Behaviour, 3(2), 165-213.

Dodds, W. B., Monroe, K. B., \& Grewal, D. (1991). Effects of price, brand, and store information on buyers' product evaluations. Journal of marketing research, 307-319.

Dornyei, Z. (2007). Research Methods in Applied Linguistics: Quantitative, Qualitative and Mixed Methodologies. Oxford University Press. Oxford.

Erdem, T., \& Swait, J. (1998). Brand equity as a signaling phenomenon. Journal of consumer Psychology, 7(2), 131-157.

Etikan, I., Musa, S. A., \& Alkassim, R. S. (2016). Comparison of convenience sampling and purposive sampling. American Journal of Theoretical and Applied Statistics, 5(1), 1-4.

Gliem, J. A., \& Gliem, R. R. (2003). Calculating, interpreting, and reporting Cronbach's alpha reliability coefficient for Likert-type scales. Midwest Research-to-Practice Conference in Adult, Continuing, and Community Education.

Green, S. B. (1991). How many subjects does it take to do a regression analysis. Multivariate behavioral research, 26(3), 499-510.

Grewal, D., Krishnan, R., Baker, J., \& Borin, N. (1998). The effect of store name, brand name and price discounts on consumers' evaluations and purchase intentions. Journal of retailing, 74(3), 331-352.

Hannerz, U. (1990). Cosmopolitans and locals in world culture. Theory, Culture \& Society, 7(2), 237-251.

Hopkins, W. G. (2008). Quantitative research design. Sportscience 4(1), sportsci.org/ jour/0001/wghdesign.html

Huang, W. Y., Schrank, H., \& Dubinsky, A. J. (2004). Effect of brand name on consumers' risk perceptions of online shopping. Journal of Consumer Behaviour, 4(1), 4050. 
Idoko, E. C., Nkamnebe, A. D., Ireneus, N. C., \& Okoye, V. I. (2013). Effects of intrinsic and extrinsic product cues on consumers'purchase intention: a study of alcoholic beverage consumers in a developing country metropolitan city. Researchers World, 4(3), 1.

Kardes, F. R., Cronley, M. L., Kellaris, J. J., \& Posavac, S. S. (2004). The role of selective information processing in price-quality inference. Journal of Consumer Research, 31(2), 368-374.

Kirmani, A., \& Zeithaml, V. (1993). Advertising, perceived quality, and brand image (pp. 143-62). Hillsdale, NJ: Lawrence Erlbaum Associates.

Kotler, P., \& Gertner, D. (2002). Country as brand, product, and beyond: A place marketing and brand management perspective. Journal of brand management, 9(4), 249-261.

Kotler, P., Keller, K. L., Manceau, D., \& Hémonnet-Goujot, A. (2015). Marketing management (Vol. 14). Englewood Cliffs, NJ: Prentice Hall.

Lee, M., \& Lou, Y. C. (1995). Consumer reliance on intrinsic and extrinsic cues in product evaluations: A conjoint approach. Journal of Applied Business Research, 12(1), 21.

Li, W. K., \& Wyer, R. S. (1994). The role of country of origin in product evaluations: Informational and standard-of-comparison effects. Journal of Consumer Psychology, 3(2), 187-212.

Lin, L. Y., \& Chen, C. S. (2006). The influence of the country-of-origin image, product knowledge and product involvement on consumer purchase decisions: an empirical study of insurance and catering services in Taiwan. Journal of consumer Marketing, 23(5), 248-265.

Malhotra, N. K. (1988). A methodology for measuring consumer preferences in developing countries. International Marketing Review, 5(3), 52-66.

Maxwell, S. (2001). An expanded price/brand effect model-A demonstration of heterogeneity in global consumption. International Marketing Review, 18(3), 325-343.

Milgrom, P., \& Roberts, J. (1986). Price and advertising signals of product quality. Journal of political economy, 94(4), 796-821.

Mitra, A. (1995). Price cue utilization in product evaluations: the moderating role of motivation and attribute information. Journal of Business Research, 33(3), 187-195.

Miyazaki, A. D., Grewal, D., \& Goodstein, R. C. (2005). The effect of multiple extrinsic cues on quality perceptions: A matter of consistency. Journal of consumer research, 32(1), 146-153.

Monroe, K. B., \& Krishnan, R. (1985). The effect of price on subjective product evaluations. Perceived quality, 1, 209-232.

Mueller, S., \& Szolnoki, G. (2010). The relative influence of packaging, labelling, branding and sensory attributes on liking and purchase intent: Consumers differ in their responsiveness. Food quality and preference, 21(7), 774-783.

Olson, J. C., \& Jacoby, J. (1972). Cue utilization in the quality perception process. In SV-proceedings of the third annual conference of the association for consumer research.

Peterson, R. A., \& Jolibert, A. J. (1995). A meta-analysis of country-of-origin effects. Journal of International business studies, 26(4), 883-900. 
Rao, A. R., \& Monroe, K. B. (1988). The moderating effect of prior knowledge on cue utilization in product evaluations. Journal of consumer research, 15(2), 253264.

Rao, A. R., \& Monroe, K. B. (1989). The effect of price, brand name, and store name on buyers' perceptions of product quality: An integrative review. Journal of marketing Research, 351-357.

Richardson, P. S., Dick, A. S., \& Jain, A. K. (1994). Extrinsic and intrinsic cue effects on perceptions of store brand quality. The Journal of Marketing, 28-36.

Santos, J. R. A. (1999). Cronbach's alpha: A tool for assessing the reliability of scales. Journal of extension, 37(2), 1-5.

Sawyer, A. G., Worthing, P. M., \& Sendak, P. E. (1979). The role of laboratory experiments to test marketing strategies. The Journal of Marketing, 60-67.

Shimp, T. A., \& Bearden, W. O. (1982). Warranty and other extrinsic cue effects on consumers' risk perceptions. Journal of Consumer research, 9(1), 38-46.

Shimp, T. A., \& Sharma, S. (1987). Consumer ethnocentrism: construction and validation of the CETSCALE. Journal of marketing research, 280-289.

Statistical Yearbook of the Republic of Kosovo for 2016. (2016). Kosovo Agency of Statistics. Retrieved 19 July 2017, from http://Kosovo Agency of Statistics.

Suen, L. J. W., Huang, H. M., \& Lee, H. H. (2014). A comparison of convenience sampling and purposive sampling. Hu Li Za Zhi, 61(3), 105.

Sukamolson, S. (2007). Fundamentals of quantitative research. Bangkok: EJTR.

Szybillo, G. J., \& Jacoby, J. (1974). Intrinsic versus extrinsic cues as determinants of perceived product quality. Journal of Applied Psychology, 59(1), 74-78.

Tavakol, M., \& Dennick, R. (2011). Making sense of Cronbach's alpha. International journal of medical education, 2, 53.

Teas, R. K., \& Agarwal, S. (2000). The effects of extrinsic product cues on consumers' perceptions of quality, sacrifice, and value. Journal of the Academy of marketing Science, 28(2), 278-290.

Tranmer, M., \& Elliot, M. (2008). Binary logistic regression. Cathie Marsh for census and survey research, paper, 20.

VanVoorhis, C. W., \& Morgan, B. L. (2007). Understanding power and rules of thumb for determining sample sizes. Tutorials in Quantitative Methods for Psychology, 3(2), 43-50.

Veale, R., Quester, P., \& Karunaratna, A. (2006). The role of intrinsic (sensory) cues and the extrinsic cues of country of origin and price on food product evaluation. In 3rd International Wine Business and Marketing Research Conference, Refereed Paper. Montpellier (pp. 6-8).

Verlegh, P. W., \& Steenkamp, J. B. E. (1999). A review and meta-analysis of countryof-origin research. Journal of economic psychology, 20(5), 521-546.

Vraneševic, T., \& Stančec, R. (2003). The effect of the brand on perceived quality of food products. British Food Journal, 105(11), 811-825.

Watson, J. J., \& Wright, K. (2000). Consumer ethnocentrism and attitudes toward domestic and foreign products. European journal of Marketing, 34(9/10), 1149-1166.

Zeithaml, V. A. (1988). Consumer perceptions of price, quality, and value: a meansend model and synthesis of evidence. The Journal of marketing, 2-22.

Zhou, K. Z., Su, C., \& Bao, Y. (2002). A paradox of price-quality and market efficiency: a comparative study of the US and China markets. International Journal of Research in marketing, 19(4), 349-365. 